\title{
San Juan de la Cruz y la lírica moderna
}

\section{Saint John of the Cross and Modern Lyrical Poetry}

\section{Felix K. E. Schmelzer}

fschmelzer@uandes.cl

\section{María Ignacia Ugarte Pérez}

miugarte1@miuandes.cl

Universidad de los Andes

CHILE

[Hipogrifo, (issn: 2328-1308), 6.2, 2018, pp. 365-368]

DOI: http://dx.doi.org/10.13035/H.2018.06.02.29

La atracción por san Juan de la Cruz no se interrumpe. Su rango en la literatura mundial es sin par. Esto tiene que ver con el estatus particular de su obra entre poesía y teología que fascinaba tanto a Paul Valéry («Cantiques spirituels», 1924). Sus versos, incomprensibles a nivel lógico-racional en los puntos culminantes de su poesía, nos sugieren musicalmente y con una riqueza insondable de imágenes la inefabilidad de la unio mystica, mientras que sus tratados teológicos, comentarios de sus tres más famosos poemas, sondean, de manera sistemática y con terminología escolástica, hasta donde llega la comprensión de esos enigmáticos textos. Así, la teología (en el sentido tradicional de la palabra) de san Juan de la Cruz se desarrolla como interpretación de poemas, un caso único en la historia del Cristianismo.

En cuanto al valor de esos dos pilares de su obra, poesía y teología, el Carmelita sugiere en el prólogo al tratado Cántico espiritual que el de la poesía es superior. Incluso nos da a entender que el intento de explicar sus versos es completamente en vano. Parece que el universo poético es demasiado complejo para ser cartografiado por la lógica humana, una comprensión, al mismo tiempo, antigua y moderna. Así, Rilke, en la famosa carta a su traductor polaco Witold Hulewicz, que le había pedido una explicación de las Elegías, constata que no puede darla porque sus poemas le trascienden infinitamente. La filosofía de Heidegger, como él mismo decía, no es otra cosa que el intento de un despliegue lógico de lo que Rilke ha cantado en forma poética. San Juan de la Cruz es el poeta que canta lo inefable y el filósofoteólogo que intenta capturar esas melodías con una terminología precisa, en una 
persona. Dada la superioridad de la palabra poética sobre la racional frente al misterio divino incluso puede constatarse, con Hans Urs von Balthasar (Herrlichkeit, II, 2), que la verdadera teología está en sus versos.

¿Puede decirse que la poesía es una especie de teología? El Carmelita probablemente contestaría con un no, aunque la afirmación inaudita del ya mencionado prólogo podría ser leída como un sí indirecto: el verdadero autor del «Cántico espiritual» es el Espíritu Santo. Esta idea implica que el poeta, cediendo la autoría, deviene un medio de expresión de fuerzas absolutas. Ya Platón entiende la poesía como una forma de enthousiasmos (Ion, 534c-e), es decir, el poeta, tocado por los dioses y privado de su razón, es llenado de un mensaje que no tiene su origen en él. A lo largo del siglo XIX, el concepto platónico de la poesía resurge una vez más en el horizonte cultural. Un ejemplo llamativo es Arthur Rimbaud con su noción del poeta vidente y proclamador del «alma universal» (Lettres voyants). La precondición para cumplir esa tarea, según Rimbaud, es una superación, incluso destrucción, del yo empírico personal que permite la conciencia del yo verdadero universal (expresado en la fórmula «Je est un autre»). De una manera tal vez parecida, el místico insiste en la idea de la muerte del yo al momento de la unio, misterio que san Juan de la Cruz canta en «Llama de amor viva»: «matando, muerte en vida la has trocado». Como indica el verso, no se trata de una muerte definitiva, sino momentánea: sigue un renacer... y un poema.

El poeta moderno, en tanto que se encuentra en las estribaciones del Romanticismo, tal vez respondería con un sí. La repugnancia de una imagen materialista y mecanicista del mundo, junto a la incapacidad de creer en la religión dogmática, han generado en él la idea de coger la religión con sus propias manos. Ya Novalis equipara el «sentimiento religioso» con el «sentimiento poético» («Die Christenheit oder Europa»); Hölderlin declara a los poetas «sacerdotes sagrados» («Brot und Wein»). La línea sigue hasta Mallarmé, quien quiere recuperar, a través de la poesía, una dimensión sagrada y «oscura» de la realidad («Le mystère dans les lettres»), y el joven Rilke, quien declara al poeta «hermano» del monje y sondea metafóricamente las profundidades de un Dios nocturno (Stundenbuch). Incluso la idea fundamental de los surrealistas de reconectar al hombre con los sueños, tal como se describe en el primer manifiesto de Bretón, revela una motivación religiosa, siendo lo inconsciente colectivo, para él, representante de lo divino. Para la modernidad, la poesía es un espacio de experimentar la trascendencia, tal vez el último.

Una poesía que quiere decir y hacer experimentable lo indecible, en plena conciencia de la imposibilidad de su tarea, y que en esa misión lleva el lenguaje a nuevas riberas -aquí está una fórmula que tal vez puede aplicarse tanto a la poesía de san Juan de la Cruz como a la lírica moderna. No sorprende que muchos poetas del siglo XX estudiaran la obra del Carmelita, y que algunos reconocieran en él un modelo ejemplar, no solo en un contexto cristiano. Al lado de la generación del 27, para la que san Juan de la Cruz es tan decisivo, al menos como Góngora (particularmente si pensamos en Lorca, Alonso y Guillén), habría que mencionar a T. S. Eliot, quien en sus Four Quartets dialogó con el místico español y le cita literalmente, a Paul Valéry, a Gabriela Mistral... Incluso varios poetas que al parecer no conocían su obra, como 
Mallarmé, siguen sus pasos estilísticos: paradoja, antítesis, categorías negativas, la nada, el silencio, la noche. De hecho, la teología negativa, tan importante para el pensamiento de san Juan de la Cruz, revela afinidades con la poética moderna. Parece que, aunque el poeta moderno no crea necesariamente en la existencia de Dios o el 'significado transcendente', es esencialmente un místico.

Como ha sugerido este esbozo pequeño e incompleto, los puntos de contacto entre la obra de san Juan de la Cruz y la lírica moderna son variados, múltiples y a veces sorprendentes. En este sentido, los estudios aquí reunidos cubren un gran territorio de temas y autores. Emilio Ricardo Báez Rivera («"Burla burlando, van los dos delante": distanciamiento declarado y acercamientos inconfesos de Jorge Luis Borges con san Juan de la Cruz») descubre un rasgo paradójico en la obra de Borges: a pesar de un desprecio casi personal de la mística, parece que hay «no pocas congruencias» entre Borges y san Juan de la Cruz que se explican sobre todo por dos experiencias místicas que el argentino pretende haber tenido. Dominique de Courcelles («Les harmoniques de la pensé mystique de Jean de la Croix. Persistances et reprises poétiques: le P. Cyprien de la Nativité de la Vierge, Paul Valéry, Rainer Maria Rilke») analiza la gran admiración por el «pensamiento puro» de san Juan de la Cruz en Valéry, quien conocía la obra del español a través de la traducción de Cyprien, y, a partir de ahí, revela características sanjuanistas en la obra de Rilke. Fabio Samuel Esquenazi, por su parte, compara la «magna nox animae» del canto LXXIV de Ezra Pound con la «noche oscura del alma» y descubre ciertas metáforas propias de la tradición mística judía en ambos autores. Rilke es otra vez el tema de la contribución de Alejandro González-Degetau («La via negationis en san Juan de la Cruz y Rainer Maria Rilke»), que destaca el concepto de la via negationis como un patrón estructural común, fijándose en el Stundenbuch del joven poeta, que en esa fase de su vida muy probablemente no conocía la obra del Carmelita. Con enfoque filosófico, Diego Honorato («Paul Valéry y lo 'místico': la lectura valeriana de san Juan de la Cruz») esboza la matriz hermenéutica de la lectura de san Juan de la Cruz que hizo Valéry en torno a la noción del "Yo puro». Acercándose a la época contemporánea, el trabajo de Elisabeth Kruse («"Poesía arraigada" y noche oscura en la lírica de Blas de Otero») descubre en la obra de Blas de Otero una corriente renovadora de la mística moderna que ejemplifica la «recontextualización del edificio místico sanjuanista en el marco de la Posguerra española». Analizando la obra del poeta mexicano contemporáneo, Javier Sicilia, con vistas a la experiencia poética de lo absoluto, Margarita León Vega («De la palabra encendida a la pasión meditada: Javier Sicilia, un poeta en busca de la experiencia de lo absoluto») muestra la relevancia de san Juan de la Cruz incluso en el siglo XXI. Mónica Montes Betancourt («San Juan de la Cruz y la literatura mística del Siglo de Oro en tres poemarios de Leopoldo Marechal»), a su vez, se detiene en las filiaciones entre la mística del Siglo de Oro y tres poemarios de Leopoldo Marechal. No dejando fuera la poesía de la segunda mitad del siglo XIX, tan decisiva para la formación de la lírica moderna, Felix Schmelzer realiza un estudio comparatista entre san Juan de la Cruz y Stéphane Mallarmé y descubre cuatro elementos neoplatónicos que estructuran el pensamiento y la poesía de ambos. Por último, Zenaida Suárez Mayor y Vicente Silva Beyer manifiestan las relaciones de transtextualidad que se dan entre 
la primera obra de Gabriela Mistral, Desolación, y la poesía del Carmelita («Huellas místicas en Desolación. Una relectura mistraliana a través de san Juan de la Cruz»).

Esperemos poder contribuir con este trabajo a entender mejor la enorme importancia de la obra de san Juan de la Cruz para nuestro propio horizonte cultural. También la poesía futura se medirá en relación con la suya. 